\title{
MANAJEMEN KURIKULUM: \\ Sebuah Kajian Teoritis
}

\author{
IBRAHIM NASBI \\ Fakultas Tarbiyah dan Keguruan, UIN Alauddin Makassar \\ Jl. HM. Yasin Limpo No. 36 Makassar \\ nasbi-ibrahim@yahoo.com
}

\begin{abstract}
:
Curriculum management is a system of curriculum management that is cooperative, comprehensive, systemic, and systematic in order to realize the achievement of curriculum objectives. A good curriculum is a curriculum that follows the development of science and technology based on society.

The management of a curriculum determines success and failure in education. Therefore, the responsibility of educational institutions and all education stakeholders should have the same vision in planning, organizing, implementing and evaluating a curriculum.
\end{abstract}

Keywords: curriculum management, educational institutions, curriculum.

\section{PENDAHULUAN}

K

urikulum adalah suatu sistem yang mempunyai komponen-komponen yang saling berkaitan erat dan menunjang satu sama lain. Komponen-komponen kurikulum tersebut terdiri dari tujuan, materi pembelajaran, metode, dan evaluasi. Dalam bentuk sistem ini kurikulum akan berjalan menuju suatu tujuan pendidikan dengan adanya saling kerja sama di antara seluruh subsistemnya. Apabila salah satu dari variabel kurikulum tidak berfungsi dengan baik, maka sistem kurikulum akan berjalan kurang baik dan maksimal.

Berangkat dari bentuk kurikulum tersebut, maka dalam pelaksanaan kurikulum, sangat diperlukan suatu pengorganisasian pada seluruh komponennya.

Dalam proses pengorganisasian ini akan berhubungan erat dengan perencanaan, pengorganisasian, pelaksanaan, dan pengawasan. Sedangkan manajemen adalah salah satu displin ilmu yang implikasinya menerapkan prosesproses tersebut. Maka dalam penerapan pelaksanaan kurikulum, seorang yang mengelola lembaga pendidikan harus menguasai ilmu manajemen, baik untuk mengurus pendidikan ataupun kurikulumnya.

\section{PENGERTIAN MANAJEMEN KURIKULUM}

Secara etimologis, istilah kurikulum berasal dari bahasa yunani, yaitu curir yang artinya "pelari" dan curere yang berarti "tempat berpacu". Istilah kurikulum berasal dari dunia olah raga, terutama dalam bidang atletik pada zaman romawi kuno. Dalam bahasa prancis, istilah kurikulum berasal dari kata courier yang berarti berlari (to run). Kurikulum berarti suatu jarak yang harus ditempuh oleh seorang pelari dari garis start sampai dengan finish untuk memperoleh medali atau penghargaan (Zainal 
Arifin, 2011: 2).

Kurikulum adalah seperangkat rencana dan pengaturan mengenai tujuan, isi, dan bahan pelajaran serta bahan yang digunakan sebagai pedoman penyelenggaraan kegiatan pembelajaran untuk mencapai tujuan pendidikan tertentu (Rusman, 2009: 3).

UU. No. 20 tahun 2003 tentang Sistem Pendidikan Nasional menyebutkan bahwa, kurikulum adalah seperangkat rencana dan pengaturan mengenai tujuan, isi, dan bahan pelajaran serta cara yang digunakan sebagai pedoman penyelenggaraan kegiatan pembelajaran untuk mencapai tujuan tertentu.

Manajemen kurikulum adalah suatu system pengelolaan kurikulum yang kooperatif, komperhensif, sistemik, dan sistematik dalam rangka mewujudkan ketercapaian tujuan kurikulum. Dalam pelaksanaannya, manajemen berbasis sekolah (MBS) dan kurikulum tingkat satuan pendidikan (KTSP). Oleh karena itu, otonomi yang diberikan pada lembaga pendidikan dalam mengelola kurikulum secara mandiri dengan memprioritaskan kebutuhan dan ketercapaian sasaran dalam visi dan misi lembaga pendidikan tidak mengabaikan kebijaksanaan nasional yang telah ditetapkan.

Keterlibatan masyarakat dalam manajemen kurikulum dimaksudkan agar dapat memahami, membantu, dan mengontrol implementasi kurikulum, sehingga lembaga pendidikan selain dituntut kooperatif juga mampu mandiri dalam mengidentifikasi kebutuhan kurikulum, mendesain kurikulum, mengendalikan serta melaporkan sumber dan hasil kurikulum, baik kepada masyarakat maupun pemerintah.

\section{RUANG LINGKUP, PRINSIP DAN FUNGSI MANAJEMEN KURIKULUM}

Manajemen kurikulum merupakan bagian integral dari kurikulum tingkat satuan pendidikan (KTSP) dan Manajemen Berbasis Sekolah (MBS). Lingkup manajemen kurikulum meliputi perencanaan, pengorganisasian, pelaksanaan dan evaluasi kurikulum. Pada tingkat satuan pendidikan kegiatan kurikulum lebih mengutamakan untuk merealisasikan dan merelevansikan antara kurikulum nasional (standar kompetensi/kompetensi dasar) dengan kebutuhan daerah dan kondisi sekolah yang bersangkutan, sehingga kurikulum tersebut merupakan kurikulum yang integritas dengan peserta didik maupun dengan lingkungan di mana sekolah itu berada.

Terdapat lima prinsip yang harus diperhatikan dalam melaksanakan manajemen kurikulum, yaitu:

a. Produktivitas, hasil yang akan diperoleh dalam kegiatan kurikulum merupakan aspek yang harus dipertimbangkan dalam manajemen kurikulum. Pertimbangan bagaimana agar peserta didik dapat mencapai hasil belajar sesuai dengan tujuan kurikulum harus menjadi sasaran dalam manajemen kurikulum.

b. Demokratisasi, pelaksanaan manajemen kurikulum harus berasaskan 
demokrasi, yang menempatkan pengelola, pelaksana dan subjek didik pada posisi yang seharusnya dalam melaksanakan tugas dengan penuh tanggung jawab untuk mencapai tujuan kurikulum

c. Kooperatif, untuk memperoleh hasil yang diharapkan dalam kegiatan manajemen kurikulum, perlu adanya kerja sama yang positif dari berbagai pihak yang terlibat.

d. Efektivitas dan efisiensi, rangkaian kegiatan manajemen kurikulum harus mempertimbngkan efektivitas dan efisiensi untuk mencapai tujuan kurikulum sehingga kegiatan manajemen kurukulum tersebut sehingga memberikan hasil yang berguna dengan biaya, tenaga, dan waktu yang relative singkat.

e. Mengarahkan visi, misi dan tujuan yang ditetapkan dalam kurikulum, proses manajemen kurikulum harus dapat memperkuat dan mengarahkan visi, misi, dan tujuan kurikulum (Rusman, 2009: 4).

Selain prinsip-prinsip tersebut juga perlu dipertimbangkan kebijaksanaan pemerintah maupun departemen pendidikan, seperti USPN No. 20 tahun 2003, kurikulum pola nasional, pedoman penyelenggaraan program, kebijaksanaan penerapan Manajemen Berbasis Sekolah, kebijaksanaan penerapan Kurikulum Tingkat Satuan Pendidikan, keputusan dan peraturan pemerintah yang berhubungan dengan lembaga pendidikan atau jenjang/ jenis sekolah yang bersangkutan.

Dalam proses pendidikan perlu dilaksanakan manajemen kurikulum agar perencanaan, pelaksanaan dan evaluasi kurikulum berjalan dengan efektif, efisien, dan optimal dalam memberdayakan berbagai sumber belajar, pengalaman belajar, maupun komponen kurikulum. Ada beberapa fungsi dari manajemen kurikulum di antaranya sebagai berikut :

a. Meningkatkan efisiensi pemanfaatan sumber daya kurikulum, pemberdayaan sumber maupun komponen kurikulum dapat ditingkatkan melalui pengelolaan yang terencana dan efektif.

b. Meningkatkan keadilan (equality) dan kesempatan pada siswa untuk mencapai hasil yang maksimal, kemampuan yang maksimal dapat dicapai peserta didik tidak hanya melalui kegiatan intrakurikuler, tetapi juga perlu melalui kegiatan ekstra dan kokurikuler yang dikelola secara integritas dalam mencapai tujuan kurikulum.

c. Meningkatkan relevansi dan efektivitas pembelajaran sesuai dengan kebutuhan peserta didik maupun lingkungan, kurikulum yang dikelola secara efektif dapat memberikan kesempatan dan hasil yang relevan dengan kebutuhan peserta didik maupun lingkungan sekitar.

d. Meningkatkan efektivitas kinerja guru maupun aktivitas siswa dalam mencapai tujuan pembelajaran, pengelolaan kurikulum yang professional, efektif, dan terpadu dapat memberikan motivasi pada kinerja guru maupun aktivitas siswa dalam belajar. 
e. Meningkatkan efisiensi dan efektivitas proses belajar mengajar, proses pembelajaran selalu dipantau dalam rangka melihat konsistensi antara desain yang telah direncanakan dengan pelaksanaan pembelajaran. Dengan demikian, ketidaksesuaian antara desain dengan implementasi dapat dihindarkan. Disamping itu, guru maupun siswa selalu termotivasi untuk melaksanakan pembelajaran yang efektif dan efisien karena adanya dukungan kondisi positif yang diciptakan dalam kegiatan pengelolaan kurikulum.

Meningkatkan partisipasi masyarakat untuk membantu pengembangan kurikulum, kurikulum yang dikelola secara professional akan melibatkan masyarakat, khususnya dalam mengisi bahan ajar atau sumber belajar perlu disesuaikan dengan ciri khas dengan kebutuhan pembangunan daerah setempat (Rusman, 2009: 5).

\section{MANAJEMEN PERENCANAAN KURIKULUM}

Maksud dari manajemen dalam perencanaan kurikulum adalah keahlian "managing" dalam arti kemampuan merencanakan dan mengorganisasikan kurikulum. Hal-hal yang perlu diperhatikan dalam proses perencanaan kurikulum adalah siapa yang bertanggung jawab dalam perencanaan kurikulum, dan bagaimana perencanaan kurikulum itu direncanakan secara professional.

Hal yang pertama dikemukakan berkenaan dengan kenyataan adanya gap atau jurang antara ide-ide strategi dan pendekatan yang dikandung oleh suatu kurikulum dengan usaha-usaha implementasinya. Gap ini disebabkan oleh masalah keterlibatan personal dalam perencanaan kurikulum. Keterlibatan personal ini banyak bergantung pada pendekatan perencanaan kurikulum yang dianut.

Pada pendekatan yang bersifat "administrative approach" kurikulum direncanakan oleh pihak atasan kemudian diturunkan kepada instansi-instansi bawahan sampai kepada guru-guru. Jadi form the top down, dari atas ke bawah atas inisiatif administrator. Dalam kondisi ini guru-guru tidak dilibatkan. Mereka lebih bersifat pasif yaitu sebagai penerima dan pelaksana di lapangan.semua ide, gagasan dan inisiatif berasal dari pihak atasan (Oemar Hamalik, 2010: 150).

Sebaliknya pada pendekatan yang bersifat "grass roots approach" yaitu yang dimulai dari bawah, yakni dari pihak guru-guru atau sekolah-sekolah secara individual dengan harapan bias meluas ke sekolah-sekolah lain. Kepala sekolah serta guru-guru dapat merencanakan kurikulum atau perubahan kurikulum karena melihat kekurangan dalam kurikulum yang berlaku. Mereka tertarik ole hide-ide baru mengenai kurikulum dan bersedia menerapkannya di sekolah mereka untuk meningkatkan mutu pelajaran.

Dengan bertindak dari pandangan bahwa guru adalah manager (the teacher as manager). J.G Owen sangat menekankan perlunya keterlibatan guru dalam perencanaan kurikulum. Guru harus ikut bertanggung jawab dalam perencanaan 
kurikulum Karena dalam praktek mereka adalah pelaksana-pelaksana kurikulum yang sudah disusun bersama (Oemar Hamalik, 2010: 151).

Di Inggris gagasan ini berwujud dalam bentuk "teacher's centeres" yang dibentuk secara local sebagai tempat guru-guru bertemu dan berdiskusi tentang pembaharuan pendidikan. Disamping guru-guru berkumpul juga pengajar dari perguruan tinggi, pengusaha dan para konsumen lulusan sekolah.

Masalah yang kedua, bagaimana kurikulum direncanakan secara professional, J.G Owen lebih menekankan pada masalah bagaimana menganalisis kondisi-kondisi yang perlu diperhatikan sebagai factor yang berpengaru $\mathrm{h}$ dalam perencanaan kurikulum.

Terdapat dua kondisi yang perlu dianalisis setiap perencanaan kurikulum:

a. Kondisi sosiokultural

Kemampuan professional manajerial menuntut kemampuan untuk dapat mengolah atau memanfaatkan berbagai sumber yang ada di masyarakat, untuk dijadikan narasumber. J.G Owen menyebutkan peranan para ahli behavior science, karena kegiatan pendidikan merupakan kegiatan behavioral dimana di dalamnya terjadi berbagai interaksi social antara guru dengan murid, murid dengan murid, dan atau guru dengan murid dengan lingkungannya.

b. Ketersediaan fasilitas

Salah satu penyebab gap antara perencana kurikulum dengan guru-guru sebagai praktisi adalah jika kurikulum itu disusun tanpa melibatkan guru-guru, dan terlebih para perencana kurang atau bahkan tidak memperhatikan kesipan guruguru di lapangan. Itulah sebabnya J.G Owen menyebutkan perlunya pendekatan "from the bottom up", yaitu pengembangan kurikulum yang berasal dari bawah ke atas (Oemar Hamalik, 2010: 151).

Menurut Peter F. Olivia, Perencanaan kurikulum terjadi pada berbagai tingkatan, dan kurikulum pekerja-guru, pengawas, administrator, atau lainnya dapat terlibat dalam upaya kurikulum pada beberapa tingkat pada waktu yang sama. semua guru yang terlibat dalam perencanaan kurikulum di tingkat kelas, guru yang paling berpartisipasi dalam kurikulum. tingkat perencanaan di mana fungsi guru dapat dikonseptualisasikan sebagai sosok yang ditunjukkan (Peter F. Olivia, 2004: 46-47).

1) Karakteristik Perencanaan Kurikulum

Perencanaan kurikulum adalah perencanaan kesempatan belajar yang dimaksudkan untuk membina siswa/ peserta didik ke arah perubahan tingkah laku yang diinginkan dan menilai hingga mana perubahan-perubahan yang terjadi pada diri siswa/ peserta didik. Kurikulum adalah semua pengalaman yang mencakup yang diperoleh baik dari dalam maupun dari luar lembaga pendidikan, yang telah direncanakan secara sistematis dan terpadu, yang bertujuan untuk mempersiapkan peserta didik mencapai tujuan pendidikan.

Tujuan perencanaan kurikulum dikembangkan dalam bentuk kerangka teori 
dan penelitian terhadap kekuatan social, pengembangan masyarakat, kebutuhan, dan gaya belajar siswa. Beberapa keputusan harus dibuat ketika merencanakan kurikulum dan keputusan tersebut harus mengarah pada spesifikasi berdasarkan criteria. Merencanakan pembelajaran merupakan bagian yang sangat penting dalam perencanaan kurikulum karena karena pembelajaran mempunyai pengaruh terhadap siswa daripada kurikulum itu sendiri (Rusman, 2009: 21).

Pimpinan perlu menyusun perencanaan secara cermat, teliti, menyeluruh dan rinci, karena memiliki multi fungsi sebagai berikut :

a) Perencanaan kurikulum berfungsi sebagai pedoman atau alat manajemen, yang berisi petunjuk tentang jenis dan sumber peserta yang diperlukan, media penyampaiannya, tindakan yang perlu dilakukan, sumber biaya, tenaga, sarana yang diperlukan, system control dan evaluasi, peran unsur-unsur ketenagaan untuk mencapai tujuan manajemen organisasi.

b) Berfungsi sebagai penggerak roda organisasi dan tata laksana untuk menciptakan perubahan dalam masyarakat sesuai dengan tujuan organisasi. Perencanaan kurikulum yang matang besar sumbangannya terhadap pembuatan keputusan oleh pimpinan, dan oleh karenanya perlu memuat informasi kebijakan yang relevan, disamping seni kepemimpinan dan pengetahuan yang telah dimilikinya.

c) Sebagai motivasi untuk melaksanakan system pendidikan sehingga mencapai hasil optimal (Oemar Hamalik, 2010: 152).

2) Model Perencanaan Kurikulum

Perencanaan kurikulum adalah suatu proses social yang kompleks yang menuntut berbagai jenis dan tingkat pembuatan keputusan kebutuhan mendiskusikan dan mengkoordinasikan proses menghendaki penggunaan model-model untuk menyajikan aspek-aspek kunci kendatipun penyajian tersebut pada gilirannya harus menyederhanakan banyak aspek dan mungkin mengabaikan beberapa aspek lainnya.sebagaimana dengan model-model pembuatan keputusan umumnya, maka rumusan suatu model perencanaan berdasarkan asumsi-asumsi rasionalitas yakni asumsi tentang pemrosesan secara cermat informasi misalnya tentang mata ajaran, siswa, lingkungan, dan hasil belajar.

Beberapa model perencanaan, yaitu :

a) Model perencanaan rasional deduktif atau rasional tyler, menitik beratkan logika dalam merancang program kurikulum dan bertitik tolak dari spesifikasi tujuan (goals and objectives) tetapi cenderung mengabaikan problematika dalam lingkungan tugas. Model itu dapat diterapkan pada semua tingkat pembuatan keputusan, misalnya rasionalisasi proyek pengembangan guru, atau menentukan kebijakan suatu planning by objecktives di lingkungan departemen. Model ini cocok un tuk system perencanaan pendidikan yang sentralistik yang menitikberatkan pada system perencanaan pusat, dimana 
kurikulum dianggap sebagai suatu alat untuk mengembangkan/ mencapai maksud-maksud di bidang social ekonomi.

b) Model interaktif rasional (the rational interactive model), memandang rasionalitas sebagai tuntutan kesepakatan antara pendapat-pendapat yang berbeda, yang tidak mengikuti urutan logic. Perencanaan kurikulum dipandang suatu masalah lebih "perencanaan dengan" (planning with) daripada perencanaan bagi (planning for). Seringkali model ini dinamakan model situasional, asumsi rasionalitasnya menekankan pada respon fleksibel kurikulum yang tidak memuskan dan inisiatif pada tingkat sekolah atau tingkat local. Hal ini mungkin merupakan suatu refleksi suatu keyakinan ideologis masyarakat demokrasi atau pengembangan kurikulum berbasis sekolah. Implementasi rencana merupakan fase krusial dalam pengembangan kurikulum, dimana diperlukan saling beradaptasi antara perencana dan pengguna kurikulum.

c) The Diciplines Model, perencanaan ini menitikberatkan pada guru-guru, mereka sendiri yang merencanakan kurikulum berdasarkan pertimbangan sistematik tentang relevansi pengetahuan filosofis, (issu-issu pengetahuan yang bermakna), sosiologi (argument-argumen kecenderungan social), psikologi (untuk memberitahukan tentang urutan-urutan materi pelajaran)

d) Model tanpa perencanaan (non planning model), adalah suatu model berdasarkan pertimbangan-pertimbangan intuitif guru-guru di dalam ruangan kelas sebagai bentuk pembuatan keputusan, hanya sedikit upaya kecuali merumuskan tujuan khusus, formalitas pendapat, dan analisis intelektual.

Keempat model perencanaan kurikulum yang dikemukakan di atas sesungguhnya merupakan tipe-tipe yang ideal (ideal types) dan bukan model-model perencanaan kurikulum aktual. Umumnya perencanaan kurikulum mengandung keempat aspek model tersebut. Namun untuk membedakannya antara satu dengan yang lainnya, diperlukan analisis variable kebermaknaan bagi praktek perencanaan. Asumsi-asumsi rasionalitas tersebut perlu disadari dalam kaitannya dengan cara memproses informasi sebagai refleksi posisi-posisi social dan ideologis yang mengatur perencanaan kurikulum.

\section{MANAJEMEN ORGANISASI KURIKULUM}

Organisasi kurikuluam adalah struktur program kurikulum yang berupa kerangka umum program-program pengajaran yang akan disampaikan kepada peserta didik. Struktur program ini merupakan dasar yang cukup esensial dalam pembinaan kurikulum dan berkaitan erat dengan tujuan program pendidikan yang hendak dicapai.

Kurikulum lebih luas daripada sekedar rencana pelajaran, tetapi meliputi segala pengalaman atau proses belajar siswa yang direncanakan dan dilaksanakan 
di bawah bimbingan lembaga pendidikan. Artinya bahwa, kurikulum bukan hanya berupa dokumen bahan cetak, melainkan rangkaian aktivitas siswa yang dilakukan dalam kelas, di laboratorium, di lapangan, maupun di lingkungan masyarakat yang direncanakan serta dibimbing oleh sekolah. Suatu kurikulum harus memuat pernyataan tujuan, menunjukkan pemilihan dan pengorganisasian bahan pelajaran serta rancangan penilaian hasil belajar. Bahkan kurikulum harus merupakan bahan pelajaran atau mata pelajaran yang dipelajari siswa, program pembelajaran, hasil pembelajaran yang diharapkan, reproduksi kebudayaan, tugas dan konsep yang mempunyai cirri-ciri tersendiri, agenda untuk rekonstruksi social, serta memberikan bekal untuk kecakapan hidup.

Salah satu aspek yang perlu dipahami dalam pengembangan kurikulum adalah aspek yang berkaitan dengan organisasi kurikulum. Organisasi kurikulum merupakan pola atau desain bahan kurikulum yang tujuannya untuk memprmudah siswa dalam mempelajari bahan pelajaran serta mempermudah siswa dalam melakukan kegiatan belajar sehingga tujuan pembelajaran dapat dicapai secara efektif.

Organisasi kurikulum sangat terkait dengan pengaturan bahan pelajaran yang ada dalam kurikulum, sedangkan yang menjadi sumber bahan pelajaran dalam kurikulum adalah nilai budaya, nilai social, aspek siswa dan masyarakat serta ilmu pengetahuan dan teknologi. Ada beberapa factor yang harus dipertimbangkan dalam organisasi kurikulum (Rusman, 2009: 60), di antaranya berkaitan dengan ruang lingkup (scope), urutan bahan (sequence), kontinuitas, keseimbangan dan keterpaduan (integrated).

Menurut Evelyn J. Sowell konsep organisasi kurikulum :

a. Subject matter designs:

1) Single subject designs

2) Correlated subjects

3) Broad fields

4) Interdisciplinary integrated studies

5) Thematic instruction

b. Society-culture-based designs/social function and activities designed

c. Learner-based designed:

1) Organic curriculum

2) Development curriculum

d. Other desigs:

1) Technology as curriculum

2) School-to-work curriculum

3) Core curriculum (Evelyn J. Sowell, tt: 135)

\section{MANAJEMEN PELAKSANAAN KURIKULUM}

Pembinaan kurikulum pada dasarnya adalah usaha pelaksanaan kurikulum di 
sekolah, sedangkan pelaksanaan kurikulum itu sendiri direalisasikan dalam proses belajar mengajar sesuai dengan prinsip-prinsip dan tuntutan kurikulum yang telah dikembangkan sebelumnya bagi suatu jenjang pendidikan atau sekolah-sekolah tertentu.

Pokok-pokok kegiatan tersebut dapat dikelompokkan menjadi 9 pokok kegiatan, yaitu :

a. Kegiatan yang berhubungan dengan tugas kepala sekolah

b. Kegiatan yang berhubungan dengan tugas guru

c. Kegiatan yang berhubungan dengan murid

d. Kegiatan yang berhubungan dengan proses belajar mengajar

e. Kegiatan-kegiatan ekstra kurikuler

f. Kegiatan pelaksanaan evaluasi

g. Kegiatan pelaksanaan pengaturan alat

h. Kegiatan dalam bimbingan dan penyuluhan

i. Kegiatan yang berkenaan dengan usaha peningkatan mutu professional guru (Evelyn J. Sowell, tt: 169).

Pelaksanaan kurikulum dibagi menjadi dua tingkatan yaitu pelaksanaan kurikulum tingkat sekolah dan tingkat kelas. Dalam tingkat sekolah yang berperan adalah kepala sekolah, dan pada tingkatan kelas yang berperan adalah guru. Walaupun dibedakan antara tugas kepala sekolah dan tugas guru dalam pelaksanaan kurikulum serta diadakan perbedaan dalam tingkat pelaksanaan administrasi, yaitu tingkat kelas dan tingkat sekolah, namun antara kedua tingkat dalam pelaksanaan administrasi kurikulumtersebut senantiasa bergandengan dan bersama-sama bertanggungjawab melaksanakan proses administrasi kurikulum.

a. Pelaksanaan kurikulum tingkat sekolah

Pada tingkatan sekolah, kepala sekolah bertanggung jawab melaksanakan kurikulum di lingkungan sekolah yang dipimpinnya. Kepala sekolah berkewajiban melakukan kegiatan-kegiatan yakni menyusun rencana tahunan, menyusun jadwal pelaksanaan kegiatan, memimpin rapat dan membuat notula rapat, membuat statistic dan menyusun laporan.

b. Pelaksanaan kurikulum tingkat kelas

Pembagian tugas guru harus diatur secara administrasi untuk menjamin kelancaran pelaksanaan kurikulum lingkungan kelas. Pembagian tugas-tugas tersebut meliputi tiga jenis kegiatan administrasi, yaitu :

1) Pembagian tugas mengajar

2) Pembagian tugas pembinaan ekstra kurikuler

3) Pembagian tugas bimbingan belajar

a. Pengembangan Kurikulum

Pengembangan kurikulum harus dilandasi oleh manajemen berdasarkan 
pertimbangan-pertimbangan multidimensional, yaitu :

1. Manajemen sebagai suatu disiplin ilmu sangat erat kaitannya dengan disiplin ilmu-ilmu lainnya, seperti filsafat, psikologi, social budaya, sosiologi dan teknologi, bahkan ilmu manajemen bayak mendapat konstribusi dari ilmu-ilmu yang lain. Banyak teori, konsep dan pendekatan dalam ilmu manajemen memberikan masukan teoritik dan fundamental bagi pengembangan kurikulum. Itu sebabnya secara konseptual teoritik ilmu manajemen harus menjadi landasan penting dalam pengembangan kurikulum. Hal ini tampak jelas konstribusi pengembangan fungsi-fungsi manajemen dalam proses pengembangan kurikulum, yang pada dasarnya sejalan dengan proses manajemen itu sendiri.

2. Para pengembang kurikulum mengikuti pola dan alur piker yang singkron dengan pola dan struktur berpikir dalam manajemen. Proses pengembangan tersebut sejalan dengan proses manajemen yakni kegiatan pengembangan dimulai dari proses perencanaan, pengorganisasian, implementasi dan control serta perbaikan. Oleh sebab itu setiap tenaga pengembang kurikulum seyogyanya menguasai ilmu manajemen.

3. Implementasi kurikulum sebagai bagian integral dalam pengembangan kurikulum yang membutuhkan konsep-konsep prinsip-prinsip dan prosedur serta pendekatan dalam manajemen. Implementasi kurikulum menuntut pelaksanaan pengorganisasian, koordinasi motivasi, pengawasan, system penunjang serta system komunikasi dan monitoring yang efektif, secara berasal dari ilmu manajemen. Dengan kata lain, tanpa memberdayakan konsep-konsep manajemen secara tepat guna, maka implementasi kurikulum tidak berlangsung secara efektif.

4. Pengembangan kurikulm tidak lepas bahkan sangat erat kaitannya dengan kebijakan dibidang pendidikan, yang bersumber dari kebijakan pembangunan nasional, kebijakan daerah, serta berbagai kebijakan sektoral.

5. Kebutuhan manajemen di sector bisnis dan industry, misalnya kebutuhan tenaga terampil yang mampu meningkatkan produktivitas perusahaan, kebutuhan demokratisasi di lingkungan semua bentuk dan jenis organisasi, adanya perspektif yang menitikberatkan pada sector manusiawi dalam proses manajemen, serta berbagai perspektif lainnya. Pada gilirannya, memberikan pengaruh penting dalam kegiatan pengembangan kurikulum (Oemar Hamalik, 2010: 261).

\section{MANAJEMEN EVALUASI KURIKULUM}

Evaluasi merupakan bagian dari sistem manajemen yaitu perencanaan, organisasi, pelaksanaan, monitoring dan evaluasi. Kurikulum juga dirancang dari tahap perencanaan, organisasi kemudian pelaksanaan dan akhirnya monitoring dan evaluasi. Tanpa evaluasi, maka tidak akan mengetahui bagaimana kondisi kurikulum 
tersebut dalam rancangan, pelaksanaan serta hasilnya.

1. Pengertian Evaluasi kurikulum

Menurut $S$ hamid, evaluasi kurikulum dan evaluasi pendidikan memiliki karakteristik yang tak terpisahkan. Karakteristik itu adalah lahirnya berbagai defenisi untuk suatu istilah teknis yang sama. Demikian juga dengan evaluasi yang diartikan oleh berbagai pihak dengan berbagai pengertian.hal tersebut disebabkan oleh filosofi keilmuan seorang yang berpengaruh terhadap metodologi evaluasi, tujuan evaluasi, dan pada gilirannya terhadap pengertian evaluasi.

Rumusan evaluasi menurut Gronlund adalah suatu proses yang sistematis dari pengumpulan, analisis dan interpretasi informasi/ data untuk menentukan sejauhamana siswa telah mencapai tujuan pembelajaran. Sementara itu, Hopkins dan Antes mengemukakan evaluasi adalah pemeriksaan secara terus menerus untuk mendapatkan informasi yang meliputi siswa, guru, program pendidikan, dan proses belajar mengajar untuk mengetahui tingkat perubahan siswa dan ketepatan keputusan tentang gambaran siswa dan efektivitas program.

Menurut Tyler, evaluasi berfokus pada upaya untuk menentukan tingkat perubahan yang terjadi pada hasil belajar. Hasil belajar tersebut biasanya diukur dengan tes. Tujuan evaluasi menurut tyler, untuk menentukan tingkat perubahan yang terjadi, baik secara statistic, maupun secara edukatif (Ibid).

Sementara itu McDonald berpendapat bahwa evaluation is the process of conceiving, obtaining and communicating information for the guidance of educational decision making with regard to a specified programme (John D. McNeil, 1990: 210). Hal senada dikemukakan oleh Stake tentang konsep responsive evaluation, yaitu pada hakikatnya evaluasi yang responsive, apabila secara langsung berorientasi pada kegiatan-kegiatan program, memberikan sambutan terhadap informasi yang diperlukan oleh audiens, dan nilai perspektifnya disajikan dalam laporan tentang keberhasilan program/kurikulum (Stake E Robert, 1967: 115).

Berdasarkan beberapa pendapat di atas, dapat disimpulkan bahwa evaluasi lebih bersifat komperhensif yang di dalamnya meliputi pengukuran. Disamping itu, evaluasi pada hakikatnya merupakan suatu proses membuat keputusan tentang nilai suatu objek. Keputusan evaluasi hanya didasarkan pada hasil pengukuran, dapat pula didasarkan pada suatu hasil pengamatan.

2. Masalah dalam Evaluasi Kurikulum

Norman dan Schmidt mengemukakan ada beberapa kesulitan dalam penerapan evaluasi kurikulum, yaitu:

1) Kesulitan dalam pengukuran, Dasar teori yang melatarbelakangi kurikulum lemah akan mempengaruhi evaluasi kurikulum tersebut. Ketidakcukupan teori dalam mendukung penjelasan terhadap hasil intervensi suatu kurikulum yang dievaluasi akan membuat penelitian (evaluasi kurikulum) tidak baik.

2) Kesulitan dalan penerapan randomisasi dan double blind. Kesulitan melakukan 
penelitian evaluasi kurikulum dengan metode randomisasi dapat disebabkan karena subjek penelitian yang akan diteliti sedikit atau kemungkinan hanya institusi itu sendiri yang melakukannya. Apabila intervensi yang digunakan hanya pada institusi tersebut maka timbul pertanyaan, "apakah mungkin mencari kelompok kontrol dan randomisasi?". Selain itu intervensi pendidikan yang dilakukan tidak memungkinkan dilakukan Blinded Dalam penelitian pendidikan khususnya penelitian evaluasi kurikulum, ditemukan kesulitan dalam menerapkan metode blinded dalam melakukan intervensi pendidikan. Dengan tidak adanya blinded maka subjek penelitian mengetahui bahwa mereka mendapat intervensi atau perlakuan sehingga mereka akan melakukan dengan serius atau sungguh-sungguh. Hal ini tentu saja dapat mengakibatkan bias dalam penelitian evaluasi kurikulum.

3) Kesulitan dalam menstandarkan intervensi dalam pendidikan. Dalam dunia pendidikan sulit sekali untuk menseragamkan sebuah perlakuan contohnya penerapan PBL yang mana memiliki berbagai macam pola penerapan. Norman (2002) mengemukakan tidak ada dosis yang standar atau fixed dalam intervensi pedidikan. Hal ini berbeda untuk penelitian di biomed seperti pengaruh obat terhadap suatu penyakit, yang mana dapat ditentukan dosis yang fixed. Berbeda dengan penelitian evaluasi kurikulum misalnya pengaruh PBL terhadap kemamuan Self Directed Learning (SDL). Penerapan PBL di berbagai FK dapat bermacam-macam. Kemungkinan penerapan SDL dalam PBL di FK A $50 \%$, sedangkan di FK B adalah $70 \%$, maka apabila mereka dijadikan subjek penelitian maka tentu saja pengaruh PBL terhadap SDL akan berbeda.

4) Pengaruh intervensi dalam pendidikan mudah dipengaruhi oleh faktor-faktor lain sehingga pengaruh intervensi tersebut seakan-akan lemah (Norman, G.R, Schdmidt H.G., 2000: 721).

\section{PENUTUP}

Manajemen kurikulum adalah seperangkat kemampuan dalam mengelola kurikulum, mulai dari perencanaan kurikulum hingga evaluasi kurikulum. Kurikulum yang baik adalah kurikulum yang mengikuti perkembangan ilmu dan teknologi yang berbasis pada masyarakat. Kegagalan dalam memanaje sebuah kurikulum akan berakibat fatal pada keberhasilan dunia pendidikan. Oleh karena itu, setiap penanggungjawab lembaga pendidikan dan seluruh stakeholder pendidikan harus memiliki visi yang sama dalam merencanakan, mengorganisasi, melaksanakan, dan mengevaluasi sebuah kurikulum. 


\section{DAFTAR PUSTAKA}

Arifin, Zainal, Konsep dan Model Pengembangan Kurikulum, Cet. I; Bandung: PT. Remaja Rosdakarya; 2011.

Hamalik, Oemar, Manajemen Pengembangan Kurikulum, Cet. IV; Bandung: PT. Remaja Rosdakarya: 2010.

McNeil, John D, Curriculum: A Comprehensif Introduction, London: Scott, Foresman/Litle, Brown Higher Education, 1990.

Olivia, Peter F., Development The Curriculum, Edisi VI; New York: Pearso Education, Inc, 2004. Rusman, Manajemen Kurikulum, (Seri II; Jakarata: PT. Raja Grafindo Persada: 2009), h. 21

Robert, Stake E, The Countenance of Education Evaluation, Teacher College 68, 1967.

Rusman, Manajemen Kurikulum, Seri II; Jakarata: PT. Raja Grafindo Persada: 2009.

Schdmidt, Norman, G.R, H.G. Effectiveness of Problem Based Learning Curricula: Theory, Practice and Paper Darts, Medical Education 2000

Sowell, Evelyn J., Curriculum An Integrative introduction, Edisi III; New York: Pearso Education, Inc. 